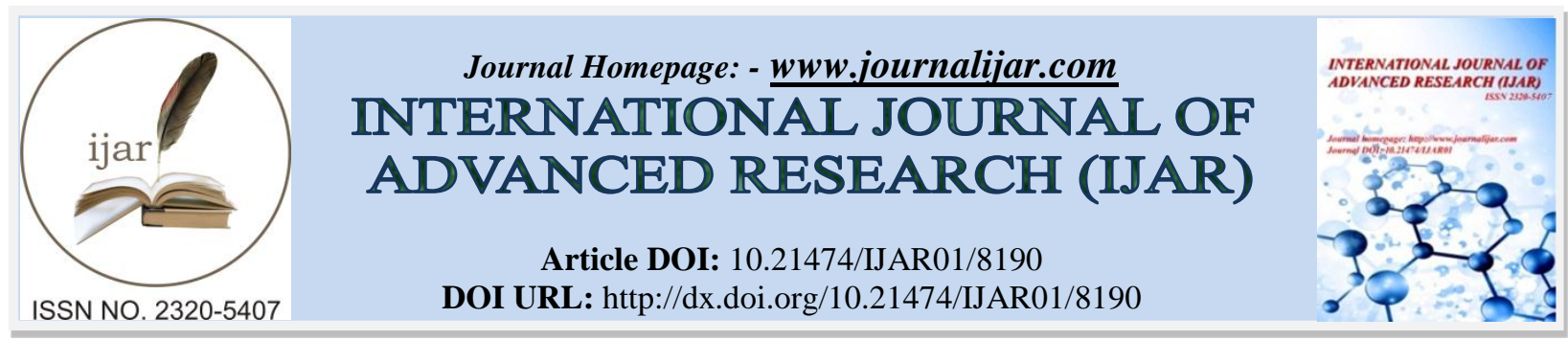

RESEARCH ARTICLE

\title{
STUDY THE EFFECT OF SILIBININ ON EXPERIMENTALLY INDUCED MEMORY IMPAIRMENT IN MALE RATS.
}

Eman Hamdy Basha, Sahar Ahmed Elsawy, Nermin Mohamed Mady and Salma Elwy Nassar. Department of medical physiology, Faculty of Medicine, Tanta University, Egypt.

\section{Manuscript Info}

\section{Manuscript History}

Received: 10 October 2018

Final Accepted: 12 November 2018

Published: December 2018

Keywords:

Silibinin, Memory impairment, Dgalactose.

\section{Abstract}

Aim of the work: is to study the effect of different doses of silibinin on D-galactose induced memory impairment in male rats.

Methods:60 male rats were divided into four groups, the first three groups were (10 rats each) and the fourth group (30 rats) was subdivided in to three subgroups (10 rats each)I-Control group was injected subcutaneously by physiological saline once daily for six weeks II- D-galactose group was injected subcutaneously by $150 \mathrm{mg} / \mathrm{kg}$ of D-galactose once daily for six weeks III-Placebo group $10 \mathrm{ml} / \mathrm{kg}$ of $0.5 \%$ carboxymethylcellulose solution was injected intraperitonealy once daily for six weeks IV-Silibinin group include $\operatorname{IVa}(2$ $\mathrm{mg} / \mathrm{kg}), \mathrm{IVb}(20 \mathrm{mg} / \mathrm{kg}), \mathrm{IVc}(200 \mathrm{mg} / \mathrm{kg})$, silibinin was suspended in $10 \mathrm{ml} / \mathrm{kg}$ of $0.5 \%$ carboxymethylcellulose solution and injected intraperitonealy once daily for six weeks.

Results: D-galactose group produced significant decrease step-through latency, increase time in the dark and increase in tissue malondialdehyde, nitrite, acetylcholine esterase, tumor necrosis factoralpha level and caspase activity, it produced significant decrease in tissue catalase activity and brain-derived neurotrophic factor level when compared to control group.There was insignificant change in placebo group and silibinin $(2 \mathrm{mg} / \mathrm{kg})$ when compared to D-galactose group.While, it produced significant change in silibinin $(20 \mathrm{mg} / \mathrm{kg})$ and $(200 \mathrm{mg} / \mathrm{kg}$ ) when compared to placebo group, but it still produced significant change in silibinin $(20 \mathrm{mg} / \mathrm{kg})$ and silibinin $(2 \mathrm{mg} / \mathrm{kg})$ when compared to control group,it produced insignificant change in silibinin $(200 \mathrm{mg} / \mathrm{kg})$ when compared to control group.

Conclusion: Silibinin has role in memory disorders which develops efficient therapeutic approaches.

Copy Right, IJAR, 2018,. All rights reserved.

\section{Introduction:-}

Silibinin (INN) is a flavonoid extracted from the medicinal plant Silybum marianum (milk thistle), is the principal component of silymarin(Song et al., 2018). Some studies show that INN has neuroprotective effects in many disorders as parkinsonism and cerebral ischemia.However,very little is known about its physiological role as neuroprotective in memory disorders which need further studies (Pandima Devi et al., 2017).Memory disorders as aging, Alzheimer's disease (AD) and related forms are among the main medical and social problems in the

Corresponding Author:-Eman Hamdy Basha.

Address:-Department of medical physiology, Faculty of Medicine, Tanta University, Egypt. 
economically developed countries (Stone et al., 2015). Aging is an important physiological form of memory impairment which lead to several cognitive disorders, there are many theories that explain the mechanism of memory ,impairment in aging, however,the potential mechanisms underlying them need further studies(Ali et al., 2015).D-galactose (D-gal) a physiological nutrient which is a reducing sugar that at higher levels is converted to oxidizing agents, these changes are considerably similar to the normal aging process and represent a model demonstrating memory impairment (Hao et al., 2014).The present study aimed to investigate the effect of silibininin at different doses against D-galactose-induced memory impairment in rats and to explore the possible mechanism of its action.

\section{Materials \& Methods:-}

The current work was carried out at Medical Physiology Department, in accordance to the guidelines of the Ethical Committee of Medical Research, Faculty of Medicine, Tanta University, Egypt to minimize animal suffering.

\section{Reagents and drugs:}

Materials including silibinin,D-galactose and carboxymethylcellulose were supplied by Sigma-Aldrich Co., USA.. Malondialdehyde (MDA), Catalase (CAT) and niyrite/nitrate reagent kits were supplied by Bio-Diagnostics Co., Giza, Egypt. Rat Tumor necrosis factor alpha (TNF-) and acetylcholine esterase ELISA kit was supplied by (Shanghai Sunred Biological Technonlgy Co., China). Rat Brain derived neurotropic factor (BDNF) ELISA kit was supplied by My BioSourceCo. USA.Caspase-3 reagent kits were supplied by Ray Biotech.

\section{Animal management:}

The present work was carried out on 60 adult male Albino rats of the local strain weighing (150-200 g). All rats were housed in isolated animal cages in room temperature in a standard animal house with free access to water and food all over the period of work. Animals were kept for two weeks for acclimatization.

\section{Experimental procedure:}

The rats were divided into three main groups as follows:

1. Group I: Control group: injected subcutaneously by $1.5 \mathrm{ml}$ physiological saline once daily for 6 week.

2. Group II: D-galactose group: $150 \mathrm{mg} / \mathrm{kg}$ of D-gal was subcutaneously injected once daily for 6 weeks(Ji et al., 2015).

3. Group III:(Placebo group): Carboxymethylcellulose (CMC) solution group: $10 \mathrm{ml} / \mathrm{kg}$ of $0.5 \% \mathrm{CMC}$ solution was given by intraperitoneal injection once daily for 6 weeks starting from the first day of D-gal injection(Duan et al., 2015).

4. Group IV: Silibinin treated group: Silibinin was given by intraperitoneal injection once daily for 6 weeks starting from the first day of D-gal injection was subdivided in to three subgroups according to the dose of silibinin (10 rats each):

5. Group Iva: Silibinin was suspended in $10 \mathrm{ml} / \mathrm{kg}$ of $0.5 \% \mathrm{CMC}$ solution and was given by intraperitoneal injection once daily at the dose of $2 \mathrm{mg} / \mathrm{kg}$ (Duan et al., 2015).

6. Group Ivb: Silibinin was suspended in $10 \mathrm{ml} / \mathrm{kg}$ of $0.5 \% \mathrm{CMC}$ solution and was given by intraperitoneal injection once daily at the dose of $20 \mathrm{mg} / \mathrm{kg}$ (Duan et al., 2015).

7. Group Ivc: Silibinin was suspended in $10 \mathrm{ml} / \mathrm{kg}$ of $0.5 \%$ CMC solution and was given by intraperitoneal injection once daily at the dose of $200 \mathrm{mg} / \mathrm{kg}$ (Duan et al., 2015).

\section{At the end of the experiment:}

Behavioral test was done in form of passive avoidance test to test memory function in all groups(Ji et al., 2015), the step through latency and time in the dark were estimated.

Passive avoidance test was performed using a two compartment chamber, one compartment was illuminated, the other was dark. At first there was training period during which each rat was received 3 trial of training with 30 minutes pause between them, in which each rat was first placed in the illuminated compartment (Ji et al., 2015). As soon as each rat entered the dark compartment, an electric shock with (frequency $50 \mathrm{~Hz}$, duration 2 second and intensity $0.8 \mathrm{~mA}$ ) was immediately delivered to the grid floor.

After 24 hour of training, each rat in the illuminated compartment, the time to enter the dark compartment (stepthrough latency in seconds) was estimated. Also, the time the rats spent in the dark compartment were estimated (Time in the dark in seconds) 
Then the rats of all groups were sacrificed, the hippocampus was dissected and following parameters were measured in its tissue:

The sacrificed animals were packed in a special package according to safety precautions and infection control measures and were sent with hospital biohazard.

\section{Biochemical analysis:}

The following parameters were measured in prepared hippocampus homogenate for all groups:MDA level: which was measured by colorimetric method (Ohkawa et al., 1979), CAT activity: which was measured by colorimetric method (Aebi, 1984), Nitrite/Nitrate level: which was measured by colorimetric method (Montgomery \&Dymock, 1961), Tumor Necrosis Factor Alpha (TNF- $\alpha$ ) assay: which was measured by ELISA (Brouckaert et al., 1993), Brain Derived Neurotrophic factor (BDNF) assay: which was measured by ELISA (Baker-Herman et al., 2004), Caspase-3 level: which was measured by ELISA (Porter \&Janicke, 1999), Acetylcholinesterase enzyme (AChE) level: which was measured by colorimetric method (Magnottl et al., 1987).

\section{Statistical analysis:-}

Results were expressed as Mean \pm SD and all statistical comparisons were made by means of one-way ANOVA test, followed by Tukey's post hoc analysis, and $\mathrm{p}$ values less than 0.05 were considered statistically significant. Analysis was performed by statistical package for the social science software (SPSS version 22.0).

\section{Results:-}

Biochemical results from the present work revealed that D-galactose group produced statistically significant decrease step-through latency, significant increase time in the dark ands tatistically significant increase in tissue MDA, nitrite, AChE, TNF- $\alpha$ level and caspase 3 activity. But it revealed statistically significant decrease in tissue catalase activity and BDNF level when compared to control group.

However, there was statistically insignificant change between these parameters in placebo group when compared to D-galactose group.

Also, there was statistically insignificant change in silibinin $(2 \mathrm{mg} / \mathrm{kg}$ ) group when compared to placebo group. While, silibinin $(20 \mathrm{mg} / \mathrm{kg})$ and $(200 \mathrm{mg} / \mathrm{kg})$ groups produced statistically significant increase step-through latency, significant decrease time in the darkand decrease in tissue MDA, nitrite, AChE, TNF- $\alpha$ level and caspase activity. But it produced statistically significant increase in tissue catalase activity and BDNF level when compared to placebo group.

In addition, silibinin $(20 \mathrm{mg} / \mathrm{kg})$ and $(200 \mathrm{mg} / \mathrm{kg})$ groups produced same statistically significant change of these parameters when compared to silibinin $(2 \mathrm{mg} / \mathrm{kg})$ group, also silibinin $(200 \mathrm{mg} / \mathrm{kg})$ group produced same statistically significant change when compared to silibinin $(20 \mathrm{mg} / \mathrm{kg})$ group.

However, silibinin $(20 \mathrm{mg} / \mathrm{kg}$ ) and silibinin $(2 \mathrm{mg} / \mathrm{kg})$ groups still produced statistically significant change of these parameters as compared to control group, but silibinin $(200 \mathrm{mg} / \mathrm{kg}$ ) group produced insignificant change as compared to control group.

\section{Discussion:-}

Chronic high dose D-gal causes significant decrease in step-through latency and significant increase time in the dark indicating deterioration of memory and cognitive skills (Zhong et al., 2016) which could be due to increase osmotic pressure with cell swelling and membrane lipid impairment with nerve degeneration caused by galactitol one of metabolites of D-gal (Wei et al., 2017) .D-gal may also results in neurological damage by A $\beta$ accumulation( Dong et al., 2017).

High dose of D-gal also produces significant decrease in tissue BDNF level as compared to control group .Pratchayasakul et al., (2017)reported that BDNF is a biomarker for neurocognitive disorders. Oxido nitrosative stress with significant increase in nitrite induced by high dose D-gal lead to increase NOS expression which causes diminished BDNF. Also, increased pro inflammatory cytokines productions activate NF-kb which inhibits BDNF production(Sulakhiya et al., 2014). 
Another mechanism, that cognitive impairment in the D-gal model has been shown to be caused by generation of ROS, This overproduction of ROS cause memory impairment by increase in oxidative damage to many molecules including lipid, protein and DNA, also it cause lipid peroxidation, protein carbonyl formation and genome instability (Vida et al., 2014).This is evidenced by significant increase in tissue MDA (Aydin et al.,2016). Over production of free radicals show increase peroxynitrite level with also significant increase in nitrite (Pratchayasakul et al., 2017).

Lu et al.,( 2012)added that NO production catalyzes a high-output pathway of NO production that is capable of causing neuronal peroxynitrite-mediated damage and dysfunction which share in memory damage, also the increase in production of ROS can be detoxified by endogenous antioxidants, causing their cellular stores to be depleted resulting insignificant decrease in catalase activity (Jangra et al.,2015).

Moreover, increase oxidative stress caused by D-gal can activate procaspase-3 resulting in apoptosis(Shahroudi et al., 2017)also the administration of D-gal increased the Bax/Bcl2 ratio and the level of caspase-3 in brain tissues which lead to a shrinkage of the cell's nucleus, to dense chromatin cells, and to apoptosis in the hippocampal neurons (Arnberg, 2015)with functional impairment of neuronal cells and eventually deterioration of memory and cognitive skills ((Shahroudi et al., 2017)

D-gal also causes inflammation as evidenced by significant increase in TNF alpha level in neuronal cells (Rehman et al., 2017).

Another mechanism of memory impairment is cholinergic neuro-degeneration that occur due to ACh depletion evidenced by significant increase in tissue AchE level (Wei et al., 2017)

The results of the present work reveal that silibinin (INN) when injected with D- gal ina low dose of, $2 \mathrm{mg} / \mathrm{kg}$ does not cause any improvement in all parameters studied compared to D-gal alone. lu et al.,(2009)reported that low dose of INN do not affect memory and cognitive skills.

However, 20and $200 \mathrm{mg} / \mathrm{kg}$ INN causes dose dependent improvement in all parameters studied compared to D-gal alone .The improvement with INN $200 \mathrm{mg} / \mathrm{kg}$ significantly reverse the effect of D-gal nearly reaching the level of the control.

20 and $200 \mathrm{mg} / \mathrm{kg}$ INN produced significant increase in step-through latency and significant decrease time in the dark during passive avoidance test indicating that INN treatment causes improvement of memory and cognitive functions (Raza et al., 2011). The protective effect of INN was supported by dose dependent significant increase BDNF, $31.36 \%$ with $20 \mathrm{mg} / \mathrm{Kg}$ INN and $63.07 \%$ with $200 \mathrm{mg} / \mathrm{kg}$ INN.

Yan et al., (2015) stated that INN maintain BDNF through suppression of oxido nitrosative stress and inhibition of NOS expression which are mediators for inhibition of BDNF .Other mechanism reported by Duan et al., (2015)that INN increase concentration of BDNF via reducing the A $\beta$ peptide level. Another point of view was that INN ameliorated inflammatory response and activated ROS-BDNF-TrkB pathway in the rat hippocampus which mean that INN decrease ROS so decrease BDNF (Song et al., 2016).

INN treatment produced significant decrease in tissue MDA $20 \mathrm{mg} / \mathrm{kg} \mathrm{9.2 \% ,} \mathrm{and} 200 \mathrm{mg} / \mathrm{kg} 17.4 \%$ on the other hand significant increase in catalase activity 10.8 with $20 \mathrm{mg} / \mathrm{kg}$ INN and $\% 21.02 \%$ with $200 \mathrm{mg} / \mathrm{kg}$.

The mechanisms underlying the neuroprotective effect of INN in D-gal groups might be attenuating oxidative damage via decreasing ROS formation(Surai, 2015). INN has transition metal ion chelating properties, due to the formation of chelates with the $\mathrm{Fe} 2+$ and inhibition of the Fenton reaction that help formation of free radicals (Gaur and Kumar, 2010).

Regoldi et al., (2017)reported thatINN increase antioxidant activityby activating a range of antioxidant enzymes and non-enzymatic antioxidants, mainly via activation of nuclear factor (erythroid-derived 2)-like 2..Also, INN significantly increase nitrite level Jangra et al., (2015), stated that INN dose-dependently decreases NO production and counter balances its oxidative damage caused by chronic high dose D-gal. Lu et al., (2009) suggested thatINN can decrease nitrite level by achieving balance between free radicals and antioxidant level by removing free radicals which is necessary for formation of peroxynitrite.

INN dose-dependently decrease tissue caspase 3 activity that INN $(200 \mathrm{mg} / \mathrm{kg})$ decrease tissue caspase activity by $38.08 \%$ more than INN $(20 \mathrm{mg} / \mathrm{kg})$ which decrease its activity by $20.2 \%$.This could be explained that INN 
suppress the expression levels of JNK/Bax/caspase-3 signaling pathway which play a critical role in activation apoptotic pathways (Bai et al., 2017), also Chauhan et al.,(2017) reported that INN inhibit oxidative stress that activate caspase 3.In addition, the anti apoptotic role of INN is due to diminishing the signal generated via either integral membrane death receptor proteins or via mitochondrial cytochrome-C release pathway, and finally reducing the expression of effector caspase-3. Results of this work also revealed that INN (200 $\mathrm{mg} / \mathrm{kg}$ ) decrease tissue AChE level 13.95 compared to $7.01 \%$ With INN $(20 \mathrm{mg} / \mathrm{kg})$.

Administration of INN could significantly restoring cholinergic neurotransmission via decreasing AChE activity( Duan et al., 2015) These result could be explained that INN alter the ACh level in cholinergic synapses by binding to the catalytic site of AChE, also Bourne et al., ( 2003) reported that INN binds to both thec entral active site and to peripheral aniotic site of $\mathrm{AChE}$ via hydrogen bonds, this hydrogen binding residues between $\mathrm{AChE}$ and INN decrease activity of AChE.

Other possible mechanism is that the effect of INN could be attributed to its potent antioxidant effects, alterations in AChE activity may be induced by the increased free radical formation which could provoke lipid peroxidation of cerebellar membranes causing changes in the conformational state of the AChE molecule and consequently inhibit its activity (Chtourou et al., 2012).

The significant decrease in tissue TNF $\alpha$ level in INN $(20$ and $200 \mathrm{mg} / \mathrm{kg})$ could be explained by that NF-kB induces expression of pro inflammatory cytokines such as IL- $1 \mathrm{~b}$ and $\mathrm{TNF} \alpha$, so inhibition of the NF- $\mathrm{kB}$ signaling pathway by INN also plays an important role in its anti-inflammatory effect (Song et al., 2016). Additionally, INN has an important ability to attenuate the levels of TNF- $\alpha$ induced by activated microglia and so decrease inflammatory responses in brain (Jung et al., 2014).Also, Jangra et al., (2015) stated that INN can ameliorate inflammatory response by reduction of oxidative stress which are mediators for inflammatory markers.

We can conclude that INN can be used as therapeutic agents in the treatment of memory disorders and cognitive dysfunction.

Table 1:-Step-through latency (seconds) in all studied groups:

\begin{tabular}{|c|c|c|c|c|c|c|}
\hline Groups & $\begin{array}{c}\text { Control } \\
\text { Group } \\
\text { I }\end{array}$ & $\begin{array}{c}\text { D-gal } \\
\text { Group } \\
\text { II }\end{array}$ & $\begin{array}{c}\text { Placebo } \\
\text { Group } \\
\text { III }\end{array}$ & $\begin{array}{c}\text { INN } \\
2 \mathrm{mg} / \mathrm{kg} \\
\text { Group IVa }\end{array}$ & $\begin{array}{c}\text { INN } \\
20 \mathrm{mg} / \mathrm{kg} \\
\text { Group IVb }\end{array}$ & $\begin{array}{c}\text { INN } \\
200 \mathrm{mg} / \mathrm{kg}\end{array}$ \\
$\begin{array}{c}\text { Mean } \\
\text { Group IVc }\end{array}$ \\
$\begin{array}{c}95 \\
\text { Palue }\end{array}$ & $\begin{array}{c}37.1 \\
\pm 9.497\end{array}$ & $\begin{array}{c}38.2 \\
\pm 9.126\end{array}$ & $\begin{array}{c}46.2 \\
\pm 7.099\end{array}$ & $\begin{array}{c}65.3 \\
\pm 11.412\end{array}$ & $\begin{array}{c}87 \\
\pm 5.793\end{array}$ \\
\hline P1 & & $\mathrm{S}$ & $\mathrm{S}$ & $\mathrm{S}$ & $\mathrm{S}$ & $\mathrm{NS}$ \\
\hline P2 & & & $\mathrm{NS}$ & $\mathrm{NS}$ & $\mathrm{S}$ & $\mathrm{S}$ \\
\hline P3 & & & & $\mathrm{NS}$ & $\mathrm{S}$ & $\mathrm{S}$ \\
\hline P4 & & & & & $\mathrm{S}$ & $\mathrm{S}$ \\
\hline P5 & & & & & & $\mathrm{S}$ \\
\hline
\end{tabular}

1. P1 is obtained in comparison to Group I.

2. $\mathrm{P} 2$ is obtained in comparison to Group II.

3. P3 is obtained in comparison to Group III.

4. P4 is obtained in comparison to Group IVa.

5. P5 is obtained in comparison to Group IVb.

( $\mathrm{P}$ value $>0.05$ is insignificant, $\quad \mathrm{P} \leq$ value 0.05 is significant) 
Table 2:-Time in the dark (seconds) in all studied group:

\begin{tabular}{|c|c|c|c|c|c|c|}
\hline Groups & $\begin{array}{c}\text { Control } \\
\text { Group } \\
\text { I }\end{array}$ & $\begin{array}{l}\text { D-gal } \\
\text { Group } \\
\text { II }\end{array}$ & $\begin{array}{c}\text { Placebo } \\
\text { Group } \\
\text { III }\end{array}$ & $\begin{array}{c}\text { INN } \\
2 \mathrm{mg} / \mathrm{kg} \\
\text { Group IVa }\end{array}$ & $\begin{array}{c}\text { INN } \\
20 \mathrm{mg} / \mathrm{kg} \\
\text { Group IVb }\end{array}$ & $\begin{array}{c}\text { INN } \\
200 \mathrm{mg} / \mathrm{kg} \\
\text { Group IVc }\end{array}$ \\
\hline $\begin{array}{c}\text { Mean } \\
\pm S D \\
\text { P value }\end{array}$ & $\begin{array}{c}10 \\
\pm 4.372\end{array}$ & $\begin{array}{c}98.1 \\
\pm 8.711\end{array}$ & $\begin{array}{c}89.5 \\
\pm 8.910\end{array}$ & $\begin{array}{c}82.2 \\
\pm 7.480\end{array}$ & $\begin{array}{c}26.8 \\
\pm 5.138\end{array}$ & $\begin{array}{c}13.6 \\
\pm 7.058\end{array}$ \\
\hline P1 & & $\mathrm{S}$ & $\mathrm{S}$ & $\mathrm{S}$ & $\mathrm{S}$ & NS \\
\hline $\mathrm{P} 2$ & & & NS & NS & $S$ & $S$ \\
\hline P3 & & & & NS & $S$ & $S$ \\
\hline P4 & & & & & $S$ & $S$ \\
\hline P5 & & & & & & $S$ \\
\hline
\end{tabular}

1. P1 is obtained in comparison to Group I.

2. $\mathrm{P} 2$ is obtained in comparison to Group II.

3. $\mathrm{P} 3$ is obtained in comparison to Group III.

4. $\mathrm{P} 4$ is obtained in comparison to Group IVa.

5. P5 is obtained in comparison to Group IVb.

( $P$ value $>0.05$ is insignificant, $\quad P \leq$ value 0.05 is significant)

Table 3:-Tissue MDA level (nmol/g) in all studied groups:

\begin{tabular}{|c|c|c|c|c|c|c|}
\hline Groups & $\begin{array}{c}\text { Control } \\
\text { Group } \\
\text { I }\end{array}$ & $\begin{array}{c}\text { D-gal Group } \\
\text { II }\end{array}$ & $\begin{array}{c}\text { Placebo } \\
\text { Group } \\
\text { III }\end{array}$ & $\begin{array}{c}\text { INN } \\
2 \mathrm{mg} / \mathrm{kg} \\
\text { Group IVa }\end{array}$ & $\begin{array}{c}\text { INN } \\
20 \mathrm{mg} / \mathrm{kg} \\
\text { Group IVb }\end{array}$ & $\begin{array}{c}\text { INN } \\
200 \mathrm{mg} / \mathrm{kg} \\
\text { Group IVc }\end{array}$ \\
\hline $\begin{array}{c}\text { Mean }_{ \pm S D} \\
\text { P. value }\end{array}$ & $\begin{array}{c}6.255 \\
\pm 0.3132\end{array}$ & $\begin{array}{c}8.016 \\
\pm 0.3270\end{array}$ & $\begin{array}{c}7.95 \\
\pm 0.4599\end{array}$ & $\begin{array}{c}7.519 \\
\pm 0.5836\end{array}$ & $\begin{array}{c}7.216 \\
\pm 0.4129\end{array}$ & $\begin{array}{c}6.565 \\
\pm 0.5692\end{array}$ \\
\hline P1 & & $S$ & $S$ & $\mathrm{~S}$ & $S$ & NS \\
\hline $\mathrm{P} 2$ & & & NS & NS & $S$ & $S$ \\
\hline P3 & & & & NS & $\mathrm{S}$ & $\mathrm{S}$ \\
\hline $\mathrm{P} 4$ & & & & & $\mathrm{~S}$ & $\mathrm{~S}$ \\
\hline P5 & & & & & & $S$ \\
\hline
\end{tabular}

1. P1 is obtained in comparison to Group I.

2. $\mathrm{P} 2$ is obtained in comparison to Group II.

3. P3 is obtained in comparison to Group III.

4. P4 is obtained in comparison to Group IVa.

5. P5 is obtained in comparison to Group IVb.

( $P$ value $>0.05$ is insignificant, $\quad P \leq$ value 0.05 is significant) 
Table 4:-Tissue catalase activity (U/g) in all studied groups:

\begin{tabular}{|c|c|c|c|c|c|c|}
\hline Groups & $\begin{array}{c}\text { Control } \\
\text { Group } \\
\text { I }\end{array}$ & $\begin{array}{c}\text { D-gal } \\
\text { Group } \\
\text { II }\end{array}$ & $\begin{array}{c}\text { Placebo } \\
\text { Group } \\
\text { III }\end{array}$ & $\begin{array}{c}\text { INN } \\
2 \mathrm{mg} / \mathrm{kg} \\
\text { Group IVa }\end{array}$ & $\begin{array}{c}\text { INN } \\
20 \mathrm{mg} / \mathrm{kg} \\
\text { Group IVb }\end{array}$ & $\begin{array}{c}\text { INN } \\
200 \mathrm{mg} / \mathrm{kg} \\
\text { Group IVc }\end{array}$ \\
\hline $\begin{array}{c}\text { Mean } \\
\text { P. value }\end{array}$ & $\begin{array}{c}8.876 \\
\pm 0.6571\end{array}$ & $\begin{array}{c}7.172 \\
\pm 0.6247\end{array}$ & $\begin{array}{c}7.182 \\
\pm 0.5377\end{array}$ & $\begin{array}{c}7.789 \\
\pm 0.4583\end{array}$ & $\begin{array}{c}7.958 \\
\pm 0.5044\end{array}$ & $\begin{array}{c}8.692 \\
\pm 0.5110\end{array}$ \\
\hline P1 & & $\mathrm{S}$ & $\mathrm{S}$ & $\mathrm{S}$ & $\mathrm{S}$ & $\mathrm{NS}$ \\
\hline P2 & & & $\mathrm{NS}$ & $\mathrm{NS}$ & $\mathrm{S}$ & $\mathrm{S}$ \\
\hline P3 & & & & $\mathrm{NS}$ & $\mathrm{S}$ & $\mathrm{S}$ \\
\hline P4 & & & & & $\mathrm{S}$ & $\mathrm{S}$ \\
\hline P5 & & & & & & $\mathrm{S}$ \\
\hline
\end{tabular}

1. P1 is obtained in comparison to Group I.

2. $\mathrm{P} 2$ is obtained in comparison to Group II.

3. P3 is obtained in comparison to Group III.

4. $\mathrm{P} 4$ is obtained in comparison to Group IVa.

5. P5 is obtained in comparison to Group IVb.

( $P$ value $>0.05$ is insignificant, $\quad P \leq$ value 0.05 is significant)

Table 5:-Tissue nitrite level ( $\mu \mathrm{mol} / \mathrm{g})$ in all studied groups:

\begin{tabular}{|c|c|c|c|c|c|c|}
\hline Groups & $\begin{array}{c}\text { Control } \\
\text { Group } \\
\text { I }\end{array}$ & $\begin{array}{c}\text { D-gal } \\
\text { Group } \\
\text { II }\end{array}$ & $\begin{array}{c}\text { Placebo } \\
\text { Group } \\
\text { III }\end{array}$ & $\begin{array}{c}\text { INN } \\
2 \mathrm{mg} / \mathrm{kg} \\
\text { Group IVa }\end{array}$ & $\begin{array}{c}\text { INN } \\
20 \mathrm{mg} / \mathrm{kg} \\
\text { Group IVb }\end{array}$ & $\begin{array}{c}\text { INN } \\
200 \mathrm{mg} / \mathrm{kg} \\
\text { Group IVc }\end{array}$ \\
\hline $\begin{array}{c}\text { Mean } \\
\text { P. value }\end{array}$ & $\begin{array}{c}27.532 \\
\pm 0.3482\end{array}$ & $\begin{array}{c}28.707 \\
\pm 0.1925\end{array}$ & $\begin{array}{c}28.727 \\
\pm 0.2386\end{array}$ & $\begin{array}{c}28.529 \\
\pm 0.1663\end{array}$ & $\begin{array}{c}28.104 \\
\pm 0.2836\end{array}$ & $\begin{array}{c}27.669 \\
\pm 0.3847\end{array}$ \\
\hline P1 & & $\mathrm{S}$ & $\mathrm{S}$ & $\mathrm{S}$ & $\mathrm{S}$ & $\mathrm{NS}$ \\
\hline P2 & & & $\mathrm{NS}$ & $\mathrm{NS}$ & $\mathrm{S}$ & $\mathrm{S}$ \\
\hline P3 & & & & NS & $\mathrm{S}$ & $\mathrm{S}$ \\
\hline P4 & & & & & $\mathrm{S}$ & $\mathrm{S}$ \\
\hline P5 & & & & & & $\mathrm{S}$ \\
\hline
\end{tabular}

1. P1 is obtained in comparison to Group I.

2. $\mathrm{P} 2$ is obtained in comparison to Group II.

3. P3 is obtained in comparison to Group III.

4. P4 is obtained in comparison to Group IVa.

5. P5 is obtained in comparison to Group IVb.

( $\mathrm{P}$ value $>0.05$ is insignificant, $\quad \mathrm{P} \leq$ value 0.05 is significant) 
Table 6:-Tissue caspase activity (OD/microgram protein) in all studied groups:

\begin{tabular}{|c|c|c|c|c|c|c|}
\hline Groups & $\begin{array}{c}\text { Control } \\
\text { Group } \\
\text { I }\end{array}$ & $\begin{array}{c}\text { D-gal } \\
\text { Group } \\
\text { II }\end{array}$ & $\begin{array}{c}\text { Placebo } \\
\text { Group } \\
\text { III }\end{array}$ & $\begin{array}{c}\text { INN } \\
2 \mathrm{mg} / \mathrm{kg} \\
\text { Group IVa }\end{array}$ & $\begin{array}{c}\text { INN } \\
20 \mathrm{mg} / \mathrm{kg} \\
\text { Group IVb }\end{array}$ & $\begin{array}{c}\text { INN } \\
200 \mathrm{mg} / \mathrm{kg} \\
\text { Group IVc }\end{array}$ \\
\hline $\begin{array}{c}\text { Mean } \\
\pm \text { SD } \\
\text { P. value }\end{array}$ & $\begin{array}{c}0.737 \\
\pm 0.05945\end{array}$ & $\begin{array}{c}1.293 \\
\pm 0.2283\end{array}$ & $\begin{array}{c}1.271 \\
\pm 0.2827\end{array}$ & $\begin{array}{c}1.237 \\
\pm 0.1565\end{array}$ & $\begin{array}{c}1.014 \\
\pm 0.08003\end{array}$ & $\begin{array}{c}0.787 \\
\pm 0.05832\end{array}$ \\
\hline P1 & & $\mathrm{S}$ & $\mathrm{S}$ & $\mathrm{S}$ & $\mathrm{S}$ & $\mathrm{NS}$ \\
\hline P2 & & & $\mathrm{NS}$ & $\mathrm{NS}$ & $\mathrm{S}$ & $\mathrm{S}$ \\
\hline P3 & & & & $\mathrm{NS}$ & $\mathrm{S}$ & $\mathrm{S}$ \\
\hline P4 & & & & & $\mathrm{S}$ & $\mathrm{S}$ \\
\hline P5 & & & & & & $\mathrm{S}$ \\
\hline
\end{tabular}

1. P1 is obtained in comparison to Group I.

2. $\mathrm{P} 2$ is obtained in comparison to Group II.

3. $\mathrm{P} 3$ is obtained in comparison to Group III.

4. $\mathrm{P} 4$ is obtained in comparison to Group IVa.

5. $\mathrm{P} 5$ is obtained in comparison to Group IVb.

( $\mathrm{P}$ value $>0.05$ is insignificant, $\quad \mathrm{P} \leq$ value 0.05 is significant)

Table 7:-Tissue AChE level (mU/ml/g) in all studied groups:

\begin{tabular}{|c|c|c|c|c|c|c|}
\hline Groups & $\begin{array}{l}\text { Control } \\
\text { Group } \\
\text { I }\end{array}$ & $\begin{array}{l}\text { D-gal } \\
\text { Group } \\
\text { II }\end{array}$ & $\begin{array}{l}\text { Placebo } \\
\text { Group } \\
\text { III }\end{array}$ & $\begin{array}{c}\text { INN } \\
2 \mathrm{mg} / \mathrm{kg} \\
\text { Group IVa }\end{array}$ & $\begin{array}{c}\text { INN } \\
20 \text { mg/kg } \\
\text { Group IVb }\end{array}$ & $\begin{array}{c}\text { INN } \\
200 \mathrm{mg} / \mathrm{kg} \\
\text { Group IVc }\end{array}$ \\
\hline $\begin{array}{l}\text { Mean }_{ \pm S D} \\
\text { P. value }\end{array}$ & $\begin{array}{c}895.96 \\
\pm 0.0620\end{array}$ & $\begin{array}{l}897.377 \\
\pm 0.5064\end{array}$ & $\begin{array}{l}897.269 \\
\pm 0.5095\end{array}$ & $\begin{array}{l}897.128 \\
\pm 0.5027\end{array}$ & $\begin{array}{c}896.64 \\
\pm 0.4985\end{array}$ & $\begin{array}{c}896.017 \\
\pm 0.06634\end{array}$ \\
\hline P1 & & $S$ & $S$ & $S$ & $S$ & NS \\
\hline $\mathrm{P} 2$ & & & NS & NS & $S$ & $S$ \\
\hline P3 & & & & NS & $\mathrm{S}$ & $\mathrm{S}$ \\
\hline P4 & & & & & $S$ & $S$ \\
\hline P5 & & & & & & $S$ \\
\hline
\end{tabular}

1. P1 is obtained in comparison to Group I.

2. $\mathrm{P} 2$ is obtained in comparison to Group II.

3. P3 is obtained in comparison to Group III.

4. P4 is obtained in comparison to Group IVa.

5. P5 is obtained in comparison to Group IVb.

( $P$ value $>0.05$ is insignificant, $\quad P \leq$ value 0.05 is significant) 
Table 8:-Tissue BDNF level(pg/g) in all studied groups:

\begin{tabular}{|c|c|c|c|c|c|c|}
\hline Groups & $\begin{array}{c}\text { Control } \\
\text { Group } \\
\text { I }\end{array}$ & $\begin{array}{c}\text { D-gal Group } \\
\text { II }\end{array}$ & $\begin{array}{c}\text { Placebo } \\
\text { Group } \\
\text { III }\end{array}$ & $\begin{array}{c}\text { INN } \\
2 \mathrm{mg} / \mathrm{kg} \\
\text { Group } \\
\text { IVa }\end{array}$ & $\begin{array}{c}\text { INN } \\
20 \mathrm{mg} / \mathrm{kg} \\
\text { Group IVb }\end{array}$ & $\begin{array}{c}\text { INN } \\
200 \mathrm{mg} / \mathrm{kg} \\
\text { Group IVc }\end{array}$ \\
\hline $\begin{array}{c}\text { Mean } \\
\pm \text { SD }\end{array}$ & $\begin{array}{c}1641.714 \\
\pm 3.576\end{array}$ & $\begin{array}{c}1625.535 \\
\pm 4.102\end{array}$ & $\begin{array}{c}1629.273 \\
\pm 3.503\end{array}$ & $\begin{array}{c}1633.438 \\
\pm 3.266\end{array}$ & $\begin{array}{c}1634.383 \\
\pm 4.072\end{array}$ & $\begin{array}{c}1639.549 \\
\pm 3.851\end{array}$ \\
\hline P. value & & S & S & S & S & NS \\
\hline P1 & & & NS & NS & S & S \\
\hline P2 & & & & NS & S & S \\
\hline P3 & & & & & S & S \\
\hline P4 & & & & & & $\mathrm{S}$ \\
\hline P5 & & & &
\end{tabular}

1. P1 is obtained in comparison to Group I.

2. $\mathrm{P} 2$ is obtained in comparison to Group II.

3. P3 is obtained in comparison to Group III.

4. P4 is obtained in comparison to Group IVa.

5. P5 is obtained in comparison to Group IVb.

( $P$ value $>0.05$ is insignificant, $\quad P \leq$ value 0.05 is significant)

Table (9):-Tissue TNF- $\alpha$ level (pg/g) in all studied groups:

\begin{tabular}{|c|c|c|c|c|c|c|}
\hline Groups & $\begin{array}{c}\text { Control } \\
\text { Group } \\
\text { I }\end{array}$ & $\begin{array}{c}\text { D-gal } \\
\text { Group } \\
\text { II }\end{array}$ & $\begin{array}{c}\text { Placebo } \\
\text { Group } \\
\text { III }\end{array}$ & $\begin{array}{c}\text { INN } \\
2 \mathrm{mg} / \mathrm{kg} \\
\text { Group IVa }\end{array}$ & $\begin{array}{c}\text { INN } \\
20 \mathrm{mg} / \mathrm{kg} \\
\text { Group IVb }\end{array}$ & $\begin{array}{c}\text { INN } \\
200 \mathrm{mg} / \mathrm{kg} \\
\text { Group IVc }\end{array}$ \\
\hline $\begin{array}{c}\text { Mean } \\
\begin{array}{|l|l|}328.177 \\
\text { P. value }\end{array}\end{array}$ & $\begin{array}{c}355.298 \\
\pm 5.022\end{array}$ & $\begin{array}{c}353.2 \\
\pm 7.576\end{array}$ & $\begin{array}{c}349.982 \\
\pm 8.011\end{array}$ & $\begin{array}{c}339.786 \\
\pm 4.285\end{array}$ & $\begin{array}{c}331.168 \\
\pm 6.451\end{array}$ \\
\hline P1 & & $\mathrm{S}$ & $\mathrm{S}$ & $\mathrm{S}$ & $\mathrm{S}$ & $\mathrm{NS}$ \\
\hline P2 & & & $\mathrm{NS}$ & $\mathrm{NS}$ & $\mathrm{S}$ & $\mathrm{S}$ \\
\hline P3 & & & & NS & $\mathrm{S}$ & $\mathrm{S}$ \\
\hline P4 & & & & & $\mathrm{S}$ & $\mathrm{S}$ \\
\hline P5 & & & & & & $\mathrm{S}$ \\
\hline
\end{tabular}

1. P1 is obtained in comparison to Group I.

2. $\mathrm{P} 2$ is obtained in comparison to Group II.

3. P3 is obtained in comparison to Group III.

4. P4 is obtained in comparison to Group IVa.

5. P5 is obtained in comparison to Group IVb.

(P value $>0.05$ is insignificant, $\quad P \leq$ value 0.05 is significant) 
Table 10:-Mean percentage of change in all studied parameters:

\begin{tabular}{|l|c|c|c|}
\hline & $\begin{array}{c}\text { INN } \\
2 \mathrm{mg} / \mathrm{kg}\end{array}$ & $\begin{array}{c}\text { INN } \\
20 \mathrm{mg} / \mathrm{kg}\end{array}$ & $\begin{array}{c}\text { INN } \\
200 \mathrm{mg} / \mathrm{kg}\end{array}$ \\
\hline Step-through latency (seconds) & $20.9 \%$ & $70.9 \%$ & $127.7 \%$ \\
\hline Time in the dark (seconds) & $8.15 \%$ & $70.05 \%$ & $84.8 \%$ \\
\hline Tissue MDA level (nmol/g) & $5.4 \%$ & $9.2 \%$ & $17.4 \%$ \\
\hline Tissue catalase activity (U/g) & $8.45 \%$ & $10.8 \%$ & $21.02 \%$ \\
\hline Tissue nitrite level ( $\mu \mathrm{mol} / \mathrm{g})$ & $0.69 \%$ & $2.16 \%$ & $3.68 \%$ \\
\hline $\begin{array}{l}\text { Tissue caspase activity (OD/ microgram } \\
\text { protein) }\end{array}$ & $2.67 \%$ & $20.2 \%$ & $38.08 \%$ \\
\hline Tissue AChE level (mU/ml/g) & $1.6 \%$ & $7.01 \%$ & $13.95 \%$ \\
\hline Tissue BDNF level(Pg/g) & $25.5 \%$ & $31.36 \%$ & $63.07 \%$ \\
\hline Tissue TNF- $\alpha$ level (pg/g) & $0.911 \%$ & $3.79 \%$ & $6.23 \%$ \\
\hline
\end{tabular}

\section{References:-}

1. Aebi, H. (1984): Catalase in vitro. Methods in Enzymology, 105: 121 -126.

2. Ali, T., Badshah, H., Kim, T.H. \& Kim, M.O (2015): Melatonin attenuates D-galactose-induced memory impairment, neuroinflammation and neurodegeneration via RAGE/ NF-KB/JNK signaling pathway in aging mouse model. Journal of Pineal Research, 58(1): 71-85.

3. Arnberg, F (2015): Cerebral blood flow and glucose metabolism in ischemic stroke: multimodal imaging investigations in a clinically relevant rat model.Klinisk Neurovetenskap, 43: 2437-2443.

4. Aydın, A.F., Coban, J., Doğan-ekici, I., Betül-Kalaz, E., Doğru-abbasoğlu, S. \& Uysal, M (2016): Carnosine and taurine treatments diminished brain oxidative stress and apoptosis in D-galactose aging model. Metabolic Brain Disease, 31(2): 337-345.

5. Bai, D., Jin, G., Yin, S., Zou, D., Zhu, Q., Yang, Z, et al., (2017): Antioxidative and Anti-Apoptotic Roles of Silibinin in Reversing Learning and Memory Deficits in APP/PS1 Mice. Neurochemical Research, 42(12): 3439-3445.

6. Baker-herman, T.L., Fuller, D.D., Bavis, R.W., Zabka, A.G., Golder, F.J., Doperalski, N.J, et al., (2004): BDNF is necessary and sufficient for spinal respiratory plasticity following intermittent hypoxia.Nature Neuroscience, 7(1): 48-55.

7. Bourne, Y., Taylor, P., Radić, Z. \& Marchot, P (2003): Structural insights into ligand interactions at the acetylcholine-sterase peripheral anionic site. The European Molecular Biology Organization Journal, 22 (1): 112.

8. Brouckaert, P., Libert, C., Everaerdt, B., Takahashi, N., Cauwels, A. \& Fiers, W (1993): Tumor necrosis factor, its receptors and the connection with interleukin 1 and interleukin 6. Immunobiology, 187(4): 317-329.

9. Chauhan, S., Singh, L., Talishetty, K. \& Kumar, V (2017): Neuroprotective effect of Silibinin against middle cerebral artery occlusion induced focal cerebral ischemia and brain injury in Wistar rats.Journal of Neuroscience and Behavioral Health, 9(1): 10-15.

10. Chtourou, Y., Fetoui, H., Garoui, E.M., Boudawara, T. \& ZeghaL, N (2012): Improvement of cerebellum redox states and cholinergic functions contribute to the beneficial effects of silymarin against manganese-induced neurotoxicity. Neurochemical Research, 37(3): 469-479.

11. Dong, F., Wang, S., Wang, Y., Yang, X., Jiang, J., Wu, D, et al., (2017): Quercetin ameliorates learning and memory via the Nrf2-ARE signaling pathway in d-galactose-induced neurotoxicity in mice. Biochemical and Biophysical Research Communications, 491(3): 636-641.

12. Duan, S., Guan, X., Lin, R., Liu, X., Yan, Y., Lin, R, et al., (2015): Silibinin inhibits acetylcholinesterase activity and amyloid $\beta$ peptide aggregation: a dual-target drug for the treatment of Alzheimer's disease. Neurobiology of Aging, 36(5): 1792-1807.

13. Gaur, V. \& Kumar, A (2010): Hesperidin pre-treatment attenuates NO-mediated cerebral ischemic reperfusion injury and memory dysfunction. Pharmacological Reports, 62(4): 635-648.

14. Hao, L., Huang, H., Gao, J., Marshall, C., Chen, Y. \& Xiao, M. (2014): The influence of gender, age and treatment time on brain oxidative stress and memory impairment induced by d-galactose in mice. Neuroscience Letters, 571: 45-49. 
15. Jangra, A., Kasbe, P., Pandey, S.N., Dwivedi, S., Gurjar, S.S., Kwatra, M, et al., (2015): Hesperidin and silibinin ameliorate aluminum-induced neurotoxicity: modulation of antioxidants and inflammatory cytokines level in mice hippocampus.Biological Trace Element Research, 168(2): 462-471.

16. Ji, Z.H., Liu, C., Zhao, H. \& Yu, X.Y (2015): Neuroprotective effect of biatractylenolide against memory impairment in D-galactose-induced aging mice. Journal of Molecular Neuroscience, 55(3): 678-683.

17. Jung, U.J., Jeon, M.T., Choi, M.S. \& Kim, S.R (2014): Silibinin attenuates MPP+-induced neurotoxicity in the substantia nigra in vivo. Journal of Medicinal Food, 17(5): 599-605.

18. Lu, P., Mamiya, T., Lu, L., Mouri, A., Ikejima, T., Kim, H.C, et al., (2012): Xanthoceraside attenuates amyloid $\beta$ peptide 25-35-induced learning and memory impairments in mice. Psychopharmacology , 219(1): $181-190$.

19. Lu, P., Mamiya, T., Lu, L., Mouri, A., Zou, L., Nagai, T, et al., (2009): Silibinin prevents amyloid $\beta$ peptideinduced memory impairment and oxidative stress in mice. British Journal of Pharmacology, 157(7): 1270-1277.

20. Magnotti, R.A., Eberly, J.P., Quarm, D. \& Mcconnell, R.S (1987): Measurement of acetylcholinesterase in erythrocytes in the field. Clinical Chemistry, 33(10): 1731-1735

21. Montgomery, H.A. \&Dymock, J.F (1961): Colorimetric determination of nitric oxide. Analyst, 86: 414-416.

22. Ohkawa, H., Ohishi, N. \& Yagi, K (1979): Assay for lipid peroxides in animal tissues by thiobarbituric acid reaction. Analytical Biochemistry, 95(2): 351-358.

23. Pandima devi, K., Sheeja Malar, D., Braidy, N., Mohammad Nabavi, S. \& Fazel nabavi, S (2017): A mini review on the chemistry and neuroprotective effects of silymarin. Current Drug Targets, 18(13): 1529-1536.

24. Porter, A.G. \& Jänicke, R.U (1999): Emerging roles of caspase-3 in apoptosis. Cell Death and Differentiation, 6(2): 99-104.

25. Pratchayasakul, W., Chattipakorn, N. \& Chattipakorn, S.C (2017): Role of D-galactose-induced brain aging and its potential used for therapeutic interventions. Experimental Gerontology, 101: 13-36.

26. Raza, S.S., Khan, M.M., Ashafaq, M., Ahmad, A., Khuwaja, G., Khan, A, et al., (2011): Silymarin protects neurons from oxidative stress associated damages in focal cerebral ischemia: a behavioral, biochemical and immunohisto-logical study in Wistar rats. Journal of The Neurological Sciences, 309(1): 45-54.

27. Reglodi, D., Renaud, J., Tamas, A., Tizabi, Y., Socías, S.B., Del-bel, E , et al., (2017): Novel tactics for neuroprotection in Parkinson's disease: role of antibiotics, polyphenols and neuropeptides. Progress in Neurobiology, 155: 120-148.

28. Rehman, S.U., Shah, S.A., Ali, T., Chung, J.I. \& Kim, M.O (2017): Anthocyanins reversed D-galactose-induced oxidative stress and neuroinflammation mediated cognitive impairment in adult rats. Molecular Neurobiology, 54(1): 255-271.

29. Shahroudi, M.J., Mehri, S. \& Hosseinzadeh, H (2017): Anti-aging effect of nigella sativa fixed oil on Dgalactose-induced aging in mice. Journal of Pharmacopuncture, 20(1): 29-35.

30. Song, X., Liu, B., Cui, L., Zhou, B., Liu, L., Liu, W, et al., (2018): Estrogen Receptors Are Involved in the Neuroprotective Effect of Silibinin in A $\beta$ 1-42-Treated Rats. Neurochemical Research, 43(4): 796-805.

31. Song, X., Zhou, B., Zhang, P., Lei, D., Wang, Y., Yao, G, et al., (2016): Protective effect of silibinin on learning and memory impairment in LPS-Treated Rats via ROS-BDNF-TrkB Pathway. Neurochemical Research, 41(7): 1662-1672.

32. Stone, J., Pal, S., Blackburn, D., Reuber, M., Thekkumpurath, P. \& Carson, A (2015): Functional (psychogenic) cognitive disorders: a perspective from the neurology clinic. Journal of Alzheimer's Disease, 48(1): 5-17.

33. Sulakhiya, K., Kumar, P., Jangra, A., Dwivedi, S., Hazarika, N.K., Baruah, C.C, et al., (2014): Honokiol abrogates lipopolysaccharide-induced depressive like behavior by impeding neuroinflammation and oxidonitrosative stress in mice. European Journal of Pharmacology, 744, 124-131.

34. Surai, P.F (2015): Silymarin as a natural antioxidant: an overview of the current evidence and perspectives. Antioxidants, 4(1): 204-247.

35. Vida, C.M., Gonzalez, E. \& De la fuente, M (2014): Increase of oxidation and inflammation in nervous and immune systems with aging and anxiety. Current Pharmaceutical Design, 20(29): 4656-4678.

36. Wei, H., Gao, Z., Zheng, L., Zhang, C., Liu, Z., Yang, Y (2017): Protective effects of fucoidan on A $\beta 25-35$ and d-Gal-induced neurotoxicity in PC12 cells and d-Gal-induced cognitive dysfunction in mice. Marine Drugs, 15(77): 1-13.

37. Yan, W.J., Tan, Y.C., Xu, J.C., Tang, X.P., Zhang, C., Zhang, P.B, et al., (2015): Protective effects of silibinin and its possible mechanism of action in mice exposed to chronic unpredictable mild stress. Biomolecules \& Therapeutics, 23(3): 245-250.

38. Zhong, L., Huang, F., Shi, H., Wu, H., Zhang, B., Wu, X, et al., (2016): Qing'E formula alleviates the aging process in D-galactose-induced aging mice. Biomedical Reports, 5(1): 101-106. 